EUROPA REGIONUM TOM XXIII ROK 2015

DOI: $10.18276 /$ er.2015.23-17

\author{
MARLENA PROCHOROWICZ \\ Zachodniopomorski Uniwersytet Technologiczny w Szczecinie
}

\title{
Działalność obiektów hotelowych w kierunku ochrony środowiska
}

\section{Wprowadzenie}

$\mathrm{W}$

ostatnich latach wzrasta ruch turystyczny nie tylko krajowy, ale również zagraniczny. Jest to umotywowane większymi dochodami obywateli, swobodą przekraczania granic, jak również chęcią poznania tradycji, kultury, sztuki oraz kuchni innych narodów. Polska dla innych nacji jest równie atrakcyjna. Według oszacowań Activ Group ${ }^{1}$ w 2013 roku było 72,3 mln przyjazdów cudzoziemców, o 8,8\% więcej niż w poprzednim roku. Liczba przyjazdów turystów szacuje się na około 15,8 mln (o 6,8\% więcej niż w 2012 r.). Jak twierdzą przybysze, do pełni szczęścia $\mathrm{w}$ turystyce brakuje w naszym regionie gwarantowanej pogody. Bogata polska baza noclegowa jest na coraz wyższym poziomie, a wykwalifikowana kadra stała się marką naszego rynku turystycznego.

Tendencję wzrostową w latach 2012-2013 (szczególnie w przypadku turystów) wzmocnił także napływ obcokrajowców na mistrzostwa Euro 2012 oraz popularność Polski w kolejnym roku. Na wzrost przyjazdów do Polski wpływ miał także wzmożony ruch odwiedzających jednodniowych. Był efektem otwarcia w lipcu 2012 roku małego ruchu granicznego z Federacją Rosyjską. (ruch przy granicy z Obwodem Kaliningradzkim).

\footnotetext{
${ }^{1}$ K. Janczak, K. Patelak, Zagraniczna turystyka przyjazdowa do Polski, Wydawnictwo Activ Group, MSiT, Łódź 2014, s. 22-28.
} 
Dzięki bogatej bazie noclegowej, gastronomicznej i kulturalnej, a także szerokiej akcji promocyjnej Polska stała się krajem często wybieranym przez turystów nie tylko europejskich.

$\mathrm{W}$ badanym okresie najwięcej miejsc noclegowych było $\mathrm{w}$ hotelach (208,6 tys.) oraz w ośrodkach wczasowych (111,8 tys.). Trzy województwa, w których było najwięcej miejsc noclegowych (pomorskie, małopolskie i zachodniopomorskie) dysponowały 298,0 tys. miejsc, co stanowiło $43,9 \%$ ich łącznej liczby w Polsce. Najwięcej miejsc noclegowych całorocznych było w województwach: małopolskim, dolnośląskim i zachodniopomorskim - razem 180 tys., czyli 38,7\% ich liczby w całej Polsce.

Województwo zachodniopomorskie posiada jedną z największych baz noclegowych w Polsce. To tutaj rozwija się bardzo prężnie turystyka uzdrowiskowa, wodna oraz agroturystyka. Pięć uzdrowisk zachodniopomorskich, tj. Dąbki, Kamień Pomorski, Kołobrzeg, Połczyn Zdrój i Świnoujście to uzdrowiska, bogate w pokłady borowiny i źródła solankowe, często wykorzystywane do zabiegów leczniczych. Również wiele gospodarstw rolnych w ramach różnicowania działalności, ze względu na odejście od produkcji roślinnej bądź zwierzęcej przygotowało swoje wolne pokoje i niezagospodarowane budynki na przyjęcie agroturystów. Baza noclegowa powiatów regionu stanowi około 12\% ogółu bazy kraju, przy powierzchni stanowiącej 7,3\% powierzchni kraju.

Najliczniejszą grupę turystycznych obiektów noclegowych w 2013 roku stanowiły ośrodki wczasowe (321 wobec 319 przed rokiem), w dyspozycji których pozostawało 41,9\% miejsc noclegowych (wobec odpowiednio 43,9\%). Znaczną część bazy turystycznej województwa stanowiły także hotele (104 wobec 93) i inne obiekty hotelowe, których liczba nie zmieniła się w ciągu roku (83). Największą liczbą miejsc, po ośrodkach wczasowych, dysponowały hotele $(13,1 \%$ wobec $10,5 \%$ przed rokiem) oraz zakłady uzdrowiskowe $(8,3 \%$ wobec $9,4 \%)^{2}$.

Turyści korzystający z obiektów noclegowych na terenie województwa zachodniopomorskiego cenią sobie wypoczynek w hotelach przyjaznych środowisku. Już nie tylko woda, powietrze i gleba powinny zdaniem kuracjuszy być czyste, ale również właściciele obiektów powinni wprowadzać działania przyczyniające się do ochrony zasobów przyrody, jak również stosować działania proekologiczne wewnątrz obiektów.

\footnotetext{
${ }^{2}$ www.stat.gov.pl
} 
Celem artykułu jest wskazanie działań proekologicznych na przykładzie wybranych obiektów turystycznych regionu zachodniopomorskiego. Autorka przeprowadziła badania $\mathrm{w}$ hotelach, ale również $\mathrm{w}$ gospodarstwach agroturystycznych. W badaniach posłużono się metodą sondażu diagnostycznego, przeprowadzonego w oparciu o wywiad kwestionariuszowy. Badaniem ankietowym, które przeprowadzono w 2013 i 2014 roku, objęto 25 hoteli oraz 25 gospodarstw agroturystycznych. Na potrzeby artykułu wybrano 10 hoteli.

\section{Turystyka zrównoważona i ekoturystyka}

Turystykę zrównoważoną można zdefiniować jako „koncepcję rozwoju turystycznego przyjaznego środowisku w regionach wiejskich oraz miastach, w małych ośrodkach turystycznych oraz wielkich centrach rozrywkowych i wypoczynkowych $(\ldots)^{3}$. Termin ekorozwój został wprowadzony w czasie I konferencji ONZ „Człowiek i środowisko” w Sztokholmie w 1972 r. Pojęcie to zostało ostatecznie sformułowane na sesji ONZ w 1975 r. Przyjęto wówczas, że społeczeństwo realizuje ideę ekorozwoju, gdy:

- uznaje nadrzędność wymogów ekologicznych, których nie należy zakłócać przez wzrost cywilizacji oraz rozwój kulturalny i gospodarczy,

- jest zdolne do samosterowania swoim rozwojem w celu utrzymania homeostazy i symbiozy z przyroda,

- respektuje oszczędną produkcję i konsumpcję oraz wykorzystywanie odpadów,

- dba o przyszłościowe konsekwencje podejmowanych działań.

Funkcjonowanie organizacji turystycznej zgodnie z zasadami ekorozwoju zapewnia:

- poszerzenie kręgu klientów i zdobycie ich lojalności,

- dobre stosunki z lokalnymi społecznościami,

- zdobycie lub poprawa „zielonego wizerunku” na tle konkurencji,

- zgodność działań z obowiązującym ustawodawstwem dotyczącym ochrony środowiska, wa 2000

${ }^{3}$ D. Zaremba, Ekoturystyka - wyzwania i nadzieje, Wydawnictwo Naukowe PWN, Warsza- 
- realizowanie zasady ciągłego doskonalenia zgodnie z ideą zrównoważonego rozwoju (ekorozwoju) ${ }^{4}$.

Od lat organizacje krajowe i międzynarodowe zajmował się promowaniem ekoturystyki, między innymi: Ecotourism Socjety (TES), World Tourism Organisation (WTO), World Resources Institute (WRI), World Widce Fund for Nature (WWF), National Audubon Society, Tourism koncern i Council of Europe (Eko Bałtyk 1999) ${ }^{5}$.

Edukacja ekologiczna, ochrona środowiska naturalnego, tradycja i kultura obszarów wiejskich jest celem działania europejskiej organizacji ECEAT (European Centra for Ecological Agriculture and Tourism), której Polska jest członkiem. Już w latach 90. XX w. ekoturystykę promowano poprzez projekt „Ekoturystyka - urlop u ekorolników".

W Polsce działa Fundacja Partnerstwo dla Środowiska, organizując wiele konkursów na dofinansowanie działań związanych z ekoturystyką, m.in. na tworzenie ekomuzeów. Z kolei Instytut na rzecz Ekorozwoju wydał publikację Ekopolityka w turystyce: raport o zmianach możliwych i potrzebnych.

Najważniejsze, to dążyć do realizacji trzech celów ekoturystyki:

- ekologicznego: zapewnienie ochrony przyrody i krajobrazu oraz kształtowanie poparcia dla terenów chronionych wśród społeczności lokalnych oraz turystów,

- społecznego: zapewnienie turystom ciekawego i wartościowego pobytu na łonie natury, poprawę jakości życia ludności miejscowej, szerzenie zasad i potrzeby rozwijania turystyki zrównoważonej oraz zagwarantowanie różnym grupom społecznym czerpania korzyści i przyjemności z istnienia terenów chronionych;

- ekonomicznego: wspieranie zrównoważonego rozwoju gospodarczego w najbardziej wrażliwych i cennych regionach świata, co przyczynia się do rozwoju gospodarki narodowej danego kraju, likwidowania bezrobocia i dostarczania środków finansowych na cele ochrony przyrody ${ }^{6}$.

\footnotetext{
${ }^{4}$ S. Kozłowski, Ekorozwój: wyzwanie XXI wieku, Wydawnictwo Naukowe PWN Warszawa 2002, w: J. Krupa, B. Wysokińska, Edukacja ekologiczna w rozwoju współczesnej turystyki, s. 244.

${ }^{5} \mathrm{~K}$. Zięba, Ekoturystyka - nadzieje z niq wiqzane, w: Turystyka i ekologia w gospodarce wolnorynkowej, red. K. Wiktorowski, Wydawnictwo Akademia Rolnicza w Szczecinie, Szczecin 2002, s. 101-104.

${ }^{6}$ R. Karczewski, Natura 2000 a Ekoturystyka, http://natura2000.org.pl/imgekoprojekty.
} 


\section{Charakterystyka wybranych obiektów turystycznych}

Turystyka jest branżą, z rozwojem której wiele osób wiąże swoją przyszłość zawodową. Tendencje światowe, europejskie i w Polsce wymuszają także na rynkach usług turystycznych konieczność inwestowania w kapitał ludzki oraz coraz większą profesjonalizację kadr zarówno bezpośrednio obsługujących ruch turystyczny, jak i zarządzających rozwojem regionalnej gospodarki turystycz$n^{{ }^{7}}{ }^{7}$. Kształcenie w tej dziedzinie umożliwia dziś wiele placówek edukacyjnych, począwszy od szczebla ponadgimnazjalnego. Licea oferują możliwość kształcenia w klasach o profilu turystyka i rekreacja czy hotelarstwo, a w technikach o profilu gastronomicznym i hotelarskim. W ofercie szkół wyższych znajdują się takie kierunki, jak turystyka i rekreacja, hotelarstwo, gospodarka turystyczna, ochrona środowiska ${ }^{8}$. Dziś możemy poszczycić się nie tylko dobrą jakością bazy noclegowej, ale również wszechstronną fachową kadrą.

W końcu lipca 2012 r. na terenie województwa znajdowały się trzy hotele oznaczone najwyższą 5-gwiazdkową kategorią (przed rokiem jeden) i 21 hoteli o 4-gwiazdkowym standardzie. Jednocześnie 29,4\% miejsc hotelowych mieściło się w 37 hotelach średniej klasy, oznaczonych 3-gwiazdkową kategorią (wobec $38,8 \%$ przed rokiem).

Jako przykłady działań proekologicznych wybrano jeden hotel pięciogwiazdkowy, trzy hotele czterogwiazdkowe, trzy hotele trzygwiazdkowe i trzy dwugwiazdkowe (tab. 1). Warto zaznaczyć, że liczba gwiazdek przy nazwie hotelu sugeruje klientom, jaki standard posiada dany hotel. Jednak w zależności od kraju poziom może być inny, mimo tej samej ilości odznaczeń. Gwiazdki mówią raczej o orientacyjnej cenie noclegu, im ich więcej, tym coraz drożej ${ }^{9}$.

${ }^{7}$ W. Fedyk, Z. Paliga, Ksztalcenie kadr dla rekreacji i turystyki jako czynnik poprawy efektywności rozwoju turystyki aktywnej na Dolnym Ślasku na przykladzie AWF Wroclaw, w: Zarzadzanie wiedza $w$ turystyce a efektywność gospodarki turystycznej (red. M. Morawski), Interior Multimedia i Wydawnictwa, AWF Wrocław 2012, s. 141-155.

${ }^{8}$ N.Kowalska-Stępień, Dzialania proekologiczne w obiektach hotelowych województwa zachodniopomorskiego, Zachodniopomorski Uniwersytet Technologiczny w Szczecinie, Szczecin 2013, s.15-16.

${ }_{9}^{9}$ http://hotelmarysienki.pl/standardy-dla-wszystkich-hoteli/standardy dla wszystkich hoteli. 
Charakterystyka wybranych hoteli województwa zachodniopomorskiego

\begin{tabular}{|l|l|c|c|c|c|}
\hline \multicolumn{1}{|c|}{$\begin{array}{c}\text { Nazwa } \\
\text { hotelu }\end{array}$} & Miejscowość & $\begin{array}{c}\text { Kategoria } \\
\text { hotelu }\end{array}$ & $\begin{array}{c}\text { Rok } \\
\text { rozpoczęcia } \\
\text { działalności }\end{array}$ & $\begin{array}{c}\text { Liczba } \\
\text { miejsc } \\
\text { noclegowych }\end{array}$ & $\begin{array}{c}\text { Liczba } \\
\text { osób } \\
\text { zatrudnionych }\end{array}$ \\
\hline Aquarius Spa & Kołobrzeg & $* * * * *$ & 2009 & 413 & 173 \\
\hline Amber Baltic & Międzyzdroje & $* * * *$ & 1991 & 372 & 204 \\
\hline Apollo & Darłowo & $* * * *$ & 2007 & 35 & 19 \\
\hline Willa Hoff & Trzęsacz & $* * * *$ & 2005 & 50 & 20 \\
\hline Alma & Barlinek & $* * *$ & 1995 & 80 & 54 \\
\hline Rycerski & Szczecin & $* * *$ & 2006 & 54 & 20 \\
\hline Wodnik Spa & $\begin{array}{l}\text { Ustronie } \\
\text { Morskie }\end{array}$ & $* * *$ & 1995 & 100 & 32 \\
\hline Ibis & Szczecin & $* *$ & 2002 & 103 & 23 \\
\hline Podzamcze & Szczecin & $* *$ & 2006 & 14 & 8 \\
\hline Resiedence & Szczecinek & $* *$ & 2001 & 27 & 13 \\
\hline
\end{tabular}

Źródło: opracowanie własne na podst. N. Kowalska-Stępień, Działania proekologiczne..., s. 42.

Do analizy celowo wybrano hotele, które rozpoczęły działalność w różnych latach oraz hotele o różnej kategorii. Mimo iż hotele Amber Baltic i Aquarius dzieli prawie dwadzieścia lat, to jednak dzisiaj bardzo podobnie przedstawiają się działania w kierunku ekologii. Wszystkie z wymienionych prowadzą działalność gastronomiczną. Modne $\mathrm{w}$ ostatnich latach usługi $\mathrm{z}$ zakresu spa\&wellness oferują prawie wszystkie hotele, zależy to w dużej mierze od wielkości hotelu, a także od zapotrzebowania wśród wypoczywających (zgodnie z wcześniej przeprowadzonym badaniem rynku przez zarządzających obiektem). Nawet jeśli nie ma typowych gabinetów czy basenów, to można przyjemnie spędzić czas w przyhotelowych siłowniach.

Zatem, jakie działania proekologiczne stosują obiekty noclegowe?

Przykładem wprowadzania działań proekologicznych jest hotel Aquarius w Kołobrzegu, gdzie zainstalowano inteligentny system zarządzania energią, co pozwala na zmniejszenie jej zużycia oraz mniejszą emisję gazów cieplarnianych. We wszystkich kranach znajdujących się w hotelu zastosowano perlatory. Dzięki nakładkom dochodzi do zwiększenia strumienia wody przez znaczne jej napowietrzenie, co pozwala zmniejszyć zużycie wody od $15 \%$ do $60 \%$. Zabiegi w Centrum Kosmetycznym przeprowadzane są na bazie produktów, które nie są testowane na zwierzętach ${ }^{10}$.

\footnotetext{
${ }^{10} \mathrm{http}: / /$ www.aquariusspa.pl/pl/hotel-spa-nad-morzem/hotel-przyjazny-srodowisku.
} 
Działania proekologiczne przejawiają się na różnych etapach świadczenia usługi. Powszechnie stosowaną metodą wpływu na decyzje konsumenckie i postawy turystów są informacje (broszury, etykiety, ulotki), które najczęściej umieszczane są w pokojach. Przykładem mogą być informacje o zakazie palenia w hotelu, oszczędzaniu energii elektrycznej, segregacji odpadów.

W działalności hoteli istotnym problemem są wytwarzane odpady w związku z dużą ilością serwowanych napojów w małych butelkach, stosowania ręczników papierowych oraz ogromną ilością odpadów opakowaniowych generowanych przez część kuchenną hotelu. Skuteczna gospodarka odpadami $\mathrm{w}$ turystyce powinna opierać się na uniwersalnej zasadzie trzech $\mathrm{R}$, a mianowicie:

- Reduce - ograniczenie ilości wytwarzanych odpadów,

- Reuse - powtórne użycie tego, co do użycia nadal się nadaje,

- Recycle - odzysk surowców ze wszystkich możliwych strumieni odpadów ${ }^{11}$.

Gospodarka odpadami realizowana jest poprzez stosowanie segregacji. Wykorzystuje się pojemniki i worki o określonym kolorze: biały na bezbarwne szkło, żółty na plastik, czerwony na metal, zielony na szkło kolorowe, niebieski na papier, czarny na odpady organiczne, szary do opakowań metalowych. Spośród badanych obiektów 53\% posiada pojemniki na baterie (53\%), puszki (7\%) i szkło (40\%).

Odpady organiczne i zlewki odbierane są z hoteli przez wyspecjalizowane firmy obsługujące dany teren w zakresie wywozu odpadów. Np. hotel Aquarius SPA przekazuje zużyty olej firmie Electrowinds Poland, która specjalizuje się w utylizacji odpadów oraz przetwarzaniu ich w energię elektryczną. Jest to jedyny przykład obiektu wykorzystującego wtórne odpady wytworzone w związku ze swoją działalnością.

W obiektach hotelowych ważne jest również wprowadzenie energooszczędnych rozwiązań technicznych, które ograniczyłyby koszty (właściwe rozmieszczenie oświetlenia, zastosowanie oświetlenia typu LED). Przykładem mogą być, oprócz energooszczędnego oświetlenia, wygaszacze światła oraz czujniki światła. Obiekty posiadają również energooszczędne urządzenia (np. windy i wieże chłodnicze).

\footnotetext{
${ }^{11}$ I. Staromiejska (red.), Czysta turystyka, czyli odpowiedź na potrzeby wspótczesnego turysty, Fundacja Partnerstwo dla Środowiska, Kraków 2011, www.fpds.pl/media.
} 
Opłacalne dla budynku może być wytwarzanie samodzielnie części lub całości potrzebnej energii. Najbardziej powszechna jest technologia słoneczna, czyli kolektory słoneczne ${ }^{12}$. Najczęściej są one montowane na dachu budynku, czasem bezpośrednio na ziemi, jeśli mają wytworzyć bardzo dużo energii. Powody prowadzenia działań ekologicznych w hotelach to m.in.: ograniczenie skutków działania hotelu na środowisko, obniżenie kosztów, korzyści marketingowe oraz lepszy wizerunek i reputacja ${ }^{13}$.

Spośród badanych obiektów, Aquarius Spa posiada własną pralnię. Ponadto hotel Aquarius Spa korzysta z usług pralni zewnętrznej. We wszystkich hotelach rozpoczęto program wymiany ręczników i pościeli na życzenie klienta. Stosowanie takich procedur pozwala na oszczędność wody, gdyż nie zawsze wszystkie ręczniki są wykorzystane przez gościa.

Ochrona środowiska to także wielokrotne wykorzystanie opakowań na żywność lub środki czystości. Najczęściej z opakowań wielokrotnego użytku lub też zwrotnych korzystały hotele o wyższym standardzie: Amber Baltic, Radisson Blu, Aquarius Spa. Tylko jeden obiekt (pięciogwiazdkowy hotel Aquarius Spa) oferuje swoim gościom ekologiczne kosmetyki, a także ekologiczną żywność.

Warto nadmienić, iż nowo powstający Baltic Park Molo w Świnoujściu będzie pierwszym kompleksem hotelowym w Polsce budowanym zgodnie z surowymi wytycznymi amerykańskiego certyfikatu (w międzynarodowym systemie Leadership in Energy and Environmental Design - LEED). Otwarcie pierwszego 5-gwiazdkowego hotelu z Aquaparkiem i promenadą zaplanowano na 2016 rok, a całego kompleksu z drugim hotelem i molo do 2020 roku. Będzie to pierwszy ,zielony” hotel w Polsce ${ }^{14}$.

Działania proekologiczne związane są również z wyższymi kosztami prowadzenia obiektu. Ze względu na wyższą jakość ceny za dobę również różnie się kształtują w poszczególnych hotelach. Ceny za miejsce noclegowe w pokoju dwuosobowym (poza sezonem) kształtują się orientacyjnie od $110 \mathrm{zl}$ (Ibis), $120 \mathrm{zł}$ (Wodnik Spa), $140 \mathrm{zł}$ (Willa Hoff, Alma), $160 \mathrm{zł}$ (Apollo), $180 \mathrm{zl}$ (Resiedence, Podzamcze), do 225 zł (Rycerski), 280 zł (Amber Baltic) i 420 zł (Aquarius Spa).

\footnotetext{
${ }^{12}$ Czysta energia, budownictwo niskoenergetyczne - nowe spojrzenie $w$ ochronie środowiska naturalnego, Urząd Marszałkowski Województwa Podkarpackiego, Rzeszów 2012.

${ }^{13}$ J. Krupa, Działania proekologiczne w turystyce szansq na jej zrównoważony rozwój, Zeszyt Naukowy TiR nr 13, Wyższa Szkoła Języków Obcych, Warszawa 2014, s. 5-23.

14 http://strefynieruchomosci.blog.pl/2014/05/27/pierwszy-zielony-hotel-w-polsce-baltic-parkmolo.
} 
Hotel Ibis Szczecin, jako jedyny z ankietowanych, brał udział w Programie Ochrony Środowiska „Goście Ziemi”, prowadził działania zmierzające do uzyskania certyfikatu ISO 14001. Głównymi czynnikami decydującymi o skutecznym wprowadzeniu ISO 14001 są polityka korporacyjna i prawodawstwo, a czynniki towarzyszące, to postrzeganie korzyści dostosowania do standardów ISO, postawa dyrekcji hotelu, tendencje rynkowe, ograniczenia handlowe, oczekiwania klientów oraz presja konkurencji.

Tabela 2

Działania proekologiczne w wybranych hotelach

\begin{tabular}{|c|c|c|c|c|c|}
\hline Nazwa hotelu & $\begin{array}{c}\text { Informacje } \\
\text { w pokojach }\end{array}$ & $\begin{array}{c}\text { Segregacja } \\
\text { odpadów }\end{array}$ & $\begin{array}{c}\text { Pralnia } \\
\text { wewnętrzna- } \\
\text { zewnętrzna }\end{array}$ & $\begin{array}{c}\text { Ekologiczna } \\
\text { żywność / } \\
\text { kosmetyki }\end{array}$ & $\begin{array}{c}\text { Oświetlenie } \\
\text { energo- } \\
\text { oszczędne }\end{array}$ \\
\hline Aquarius Spa & + & + & $Z$ & + & + \\
\hline Amber Baltic & + & + & $\mathrm{Z}$ & + & + \\
\hline Apollo & + & + & $\mathrm{W} / \mathrm{Z}$ & + & + \\
\hline Willa Hoff & + & + & $\mathrm{Z}$ & + & + \\
\hline Alma & + & + & $\mathrm{Z}$ & - & + \\
\hline Rycerski & - & - & $\mathrm{Z}$ & - & - \\
\hline Wodnik Spa & + & + & $\mathrm{Z}$ & + & + \\
\hline Ibis & + & + & $\mathrm{Z}$ & - & + \\
\hline Podzamcze & + & - & $\mathrm{Z}$ & - & - \\
\hline Resiedence & + & - & $\mathrm{Z}$ & - & + \\
\hline
\end{tabular}

Źródło: opracowanie własne na podst. N. Kowalska-Stępień, Działania proekologiczne..., s. 57.

Istnieją jednak pewne bariery w podejmowaniu działań proekologicznych, a są to najczęściej:

- dostrzeganie niepowodzeń we wdrażaniu i realizacji polityki proekologicznej na rynku (niski efekt konkurencyjności),

- niedostateczna wiedza w zakresie działań proekologicznych,

- priorytety ekonomiczne nad ekologicznymi (brak zaufania i sprzeczność celów),

- większe koszty działań bieżących oraz inwestycji,

- wyższa cena usług, a tym samym ograniczenie popytu,

- różne postrzeganie usprawnień i korzyści,

- brak funduszy kapitałowych ${ }^{15}$.

${ }^{15}$ J. Krupa, K. Krupa, Działania proekologiczne czynnikiem konkurencyjności w sektorze ustug, w: Innowacje ekologiczne w rozwoju społeczno-gospodarczym, red. L. Woźniak, J. Krupa, J. Grzesik, Wydawnictwo WSIiZ, Rzeszów 2006, s. 115-132. 


\section{Podsumowanie}

Warto zwracać uwagę na pomoc państwa polskiego i organizacji pozarządowych, by promować ekoturystykę poprzez kampanie informujące turystów o pozytywnym i negatywnym wpływie ich zachowań na środowisko. Działania w kierunku poprawy i ochrony środowiska powinny dotyczyć oznakowania obiektów turystycznych, usług, informacji dla odwiedzających. Taka akcja informująca i propagująca ochronę środowiska powinna być rozpoczęta już w szkołach podstawowych, a poprzez zabawę także wśród przedszkolaków, przyszłych turystów.

Wyzwania środowiskowe wymagają wdrożenia nowych wzorców postępowania przez właścicieli obiektów oraz personelu. Podstawą będzie tu odpowiedni proces szkolenia. Stworzenie procedur i przestrzeganie ich może w znacznej mierze przyczynić się do wymiernych rezultatów w zakresie ochrony środowiska. W badanych obiektach turystycznych odbywały się szkolenia, w których uczestniczyli pracownicy hoteli: Aquarius Spa, Ibis, Wodnik Spa, Amber Baltic. Szkolenia takie odbywały się co roku, w zależności od potrzeb i zmiany kadry. Przykładem może być „Ekologia w turystyce - to się opłaca”, projekt współfinansowany ze środków Unii Europejskiej.

Często wdrożenie rozwiązań prośrodowiskowych w hotelach napotyka na przeszkody. Pierwszą jest połączenie aspektów środowiskowych z podstawowymi funkcjami hotelu. Ten problem może dotyczyć każdego obiektu, bez względu na jego lokalizację i wielkość. Druga przeszkoda to wpływ globalnych warunków społeczno-politycznych i ekonomicznych na przemysł turystyczny. Warunki te mogą kształtować rentowność hoteli, a to ma znaczenie przy pozyskiwaniu funduszy na kapitałochłonne rozwiązania technologiczne. Trzecią przeszkodą może być rosnący sceptycyzm wobec wprowadzenia globalnych standardów środowiskowych ${ }^{16}$.

${ }^{16}$ A. Kasim, Towards a wider adoption of environmental responsibility in the hotel sector, „International Journal of Hospitality and Tourism Administration” 2007, no. 8, s. 25-49, za M. Stuczyński, Odpowiedzialność hotelarstwa za środowisko w kontekście turystyki zrównoważonej, w: A. Rapacz (red.), Wyzwania wspótczesnej polityki turystycznej. Problemy funkcjonowania rynku turystycznego, Prace Naukowe Uniwersytetu Ekonomicznego we Wrocławiu nr 258, Wrocław 2012, s. 85. 


\section{Bibliografia}

Janczar K., Patelak K., Zagraniczna turystyka przyjazdowa do Polski, Wydawnictwo Activ Group, MSiT, Łódź 2014.

Kasim A., Towards a wider adoption of environmental responsibility in the hotel sector, „International Journal of Hospitality and Tourism Administration”, 2007, no. 8, s. 25-49, za M. Stuczyński, Odpowiedzialność hotelarstwa za środowisko w kontekście turystyki zrównoważonej, w: A. Rapacz (red.) Wyzwania wspótczesnej polityki turystycznej. Problemy funkcjonowania rynku turystycznego. Prace Naukowe Uniwersytetu Ekonomicznego we Wrocławiu nr 258, 2012.

Karczewski R., Natura 2000 a Ekoturystyka, http://natura2000.org.pl/imgekoprojekty.

Kowalska-Stępień N., Działania proekologiczne w obiektach hotelowych województwa zachodniopomorskiego, Zachodniopomorski Uniwersytet Technologiczny w Szczecinie, Szczecin 2013.

Kozłowski S. Ekorozwój: wyzwanie XXI wieku, w: J. Krupa, B. Wysokińska, Edukacja ekologiczna w rozwoju wspótczesnej turystyki, Wydawnictwo Naukowe PWN, Warszawa 2002.

Krupa J., Działania proekologiczne w turystyce szansq na jej zrównoważony rozwój, Zeszyt Naukowy TiR nr 13, Wyższa Szkoła Języków Obcych, Warszawa 2014.

Milewska M., Włodardzyk B., Hotelarstwo, Wyższa Szkoła Turystyczna w Łodzi, Łódź 2005,

Staromiejska I. (red.), Czysta turystyka, czyli odpowiedź na potrzeby wspótczesnego turysty, Fundacja Partnerstwo dla Środowiska, Kraków 2011, www.fpds.pl/media.

Zaremba D., Ekoturystyka - wyzwania i nadzieje, Wydawnictwo Naukowe PWN, Warszawa 2000.

Zięba K., Ekoturystyka - nadzieje z niq wiqzane, w: Turystyka i ekologia w gospodarce wolnorynkowej, red. K. Wiktorowski, Wydawnictwo Akademia Rolnicza w Szczecinie, Szczecin 2002, s. 101-104.

Strategia Rozwoju Województwa Zachodniopomorskiego do 2020 roku, Szczecin 2005.

http://www.aquariusspa.pl/pl/hotel-spa-nad-morzem/hotel-przyjazny-srodowisku. http://strefynieruchomosci.blog.pl/2014/05/27/pierwszy-zielony-hotel-w-polsce-baltic-parkmolo.

http:/hotelmarysienki.pl/standardy-dla-wszystkich-hoteli/standardy dla wszystkich hoteli. www.stat.gov.pl 


\section{Activity of hotel facilities towards the environmental protection}

\section{Summary}

The tourists using accommodation facilities in West Pomerania province appreciate a holiday in environmentally friendly hotels. Not only water, air and soil should be clean, according to patients and customers, but also the owners should contribute to the protection of natural resources, as well as be focused on eco-friendly activities inside the buildings. This article aims to identify environmental actions on selected tourist facilities of West Pomeranian region. The author conducted a study in hotels and agritourism farms. The diagnostic survey based on a structured interview was used as a method of research. The survey, which was conducted in 2013, included 10 hotels and 10 agritoursm farms. The hotels of different categories were selected for the analysis in order to compare their environmental activities. 